\title{
International Human Rights: bases for Indigenous rights
}

\author{
Garth Nettheim
}

\section{Introduction}

This paper discusses two aspects in which International Human Rights Law may be relevant to the discussion of a treaty between Indigenous and non-Indigenous Australia. First, international human rights norms may provide a basis for the concept of a treaty between a State and the Indigenous peoples within the boundaries of that State. Second, these norms, particularly those codified in various human rights treaties and other instruments can provide a basis for the content of any such instrument.

\section{The concept of a treaty}

\section{Defining 'Treaty'}

Until fairly recent times, the word 'treaty' was used for any sort of agreement or compact. Even today, the term 'private treaty' is used if one buys a house other than at auction. But dictionaries now use the term in the more limited sense of 'a formal agreement between two or more independent states' and 'the formal document embodying such an international agreement'. The 1969 Vienna Convention on the Law of Treaties defines the term, for the purpose of the Convention, as 'an international agreement concluded between States in written form and governed by international law, whether embodied in a single instrument or in two or more related instruments and whatever its particular designation'.2

\section{Defining 'State'}

If we proceed with this modern, limited definition of what is a 'treaty', what, then, is a 'State'? Can we say that Aboriginal and Torres Strait Islander peoples constituted States, such that the term 'treaty' would have been appropriate at the beginning of contact with Britain? Even if they did constitute States at that time, can we say that they still have the essential characteristics of States today, such that any agreement now between them and Australia would merit the term 'treaty'?

Again, modern International Law offers a widely accepted definition of the term 'State'. The Restatement of the Law (Third). The Foreign Relations Law of the United States ${ }^{3}$ follows the Montevideo Convention on the Rights and Duties of States ${ }^{4}$ and defines a State as having the following characteristics:

\footnotetext{
${ }^{1}$ The Macquarie Dictionary 1997: 2253. An additional definition as encompassing 'any agreement or compact' is regarded as obsolete by The Oxford English Dictionary 1970: 309.

${ }^{2}$ Vienna Convention, Article 2, para 1(a).

${ }^{3}$ Restatement 1987: para 201.

${ }^{4}$ Montevideo Convention December 1933: Article I.
} 
Under International law, a state is an entity that has a defined territory and permanent population, under the control of its own government, and that engages in, or has the capacity to engage in, formal relations with other such entities.

An additional element is recognition by other States. This State-centred concept of International Law was largely developed by European nations which had their own conceptions of the sort of characteristics - particularly the sort of governmental structures - that would merit recognition.

\section{Treaties with Indigenous peoples}

By and large, European nations acknowledged the political authority and the sovereignty of non-European peoples in those territories where they wished to establish permanent settlements. They did so by negotiating formal treaties with them. This was British imperial policy and practice in North America and the Pacific and elsewhere. Consider the Admiralty's secret instructions in 1768 to Lt James Cook for his first great voyage into the Pacific in the event that he should discover the Great South Land:

You are also with the consent of the natives to take possession of convenient situations in the country in the name of the King of Great Britain, or, if you find the country uninhabited take possession for His Majesty the King by setting up proper marks and inscriptions as first discoverers and possessors. ${ }^{5}$

When Cook made landfall on the eastern coast of what is now called Australia in 1770, he did encounter natives, but did not gain their consent before he proclaimed British sovereignty at Possession Island. His reasons were various and, apparently, involved some degree of erroneous speculation that the land was literally uninhabited (terra nullius), apart from small groups living on the coastal fringes. ${ }^{6}$

But at least the Government's policy had been clearly stated. It was subsequently followed more faithfully when Britain asserted sovereignty over New Zealand on the basis of the Treaty of Waitangi. The policy had been followed previously in the settlement of North America, and was followed by the US Government as it expanded across the continent. The policy was followed in Canada which still negotiates treaties with First Nations today.

The US Congress expressly forbade the negotiation of any more treaties in 1871:

hereafter no Indian nation or tribe within the territory of the United States shall be acknowledged or recognised as an independent nation, tribe or power with whom the United States may contract by treaty: Provided, further, That nothing herein contained shall be construed to invalidate or impair the obligation of any treaty heretofore lawfully made and ratified with any such Indian nation or tribe. ${ }^{7}$

However, Professor Charles F Wilkinson points out that much of what had previously been achieved by treaties continued to be achieved through a variety of other government acts which he designates 'treaty substitutes'. ${ }^{8}$

\footnotetext{
$\begin{array}{lll}{ }^{5} \text { Cited in Bennett and Castles 1979: 253-4 } & { }^{6} \text { Reynolds 1987: 31-3, 51, 53, 54. } & { }^{8} \text { Wilkinson 1987: 8, 63-8, 101-3. } \\ \text { (emphasis added). } & 7 \text { Indian Appropriations Act of 1871 (USA). }\end{array}$
} 


\section{Indigenous peoples in International law}

Professor S James Anaya has argued persuasively that what are now termed Indigenous peoples were regarded as subjects of International Law until well into the nineteenth century when the settler States proceeded to deny any such status and to 'domesticate' them. ${ }^{9}$ Arguably, they are still subjects of International law today. ${ }^{10}$

\section{Defining 'Indigenous peoples'}

At this stage, it is appropriate to consider an accepted International Law definition of the term 'Indigenous peoples'. The Indigenous peoples of the world have long and bitter experience of being subjected to definitions imposed on them by settler States, and they have resisted moves to include a definition in the UN Draft Declaration on the Rights of Indigenous Peoples. Their argument was that it was for Indigenous peoples themselves to identify themselves. But Martinez Cobo, in his Study of the Problem of Discrimination against Indigenous Populations for the UN Sub-Commission on Prevention of Discrimination and Protection of Minorities, offered a working description which has been cited on many occasions:

Indigenous communities, peoples and nations are those which, having a historical continuity with pre-invasion and pre-colonial societies that developed on their territories, consider themselves distinct from other sectors of the societies now prevailing in those territories, or parts of them. They form at present non-dominant sectors of society and are determined to preserve, develop and transmit to future generations their ancestral territories, and their ethnic identity, as the basis of their continued existence as peoples, in accordance with their own cultural patterns, social institutions and legal systems ...

On an individual basis, an indigenous person is one who belongs to those indigenous populations through self-identification as indigenous (group consciousness) and is recognized and accepted by those populations as one of its members (accepted by the group). ${ }^{11}$

The Treaty study

Miguel Alfonso Martinez, as a UN Special Rapporteur, conducted a Study on treaties, agreements and other constructive arrangements between States and indigenous populations. He produced for the Sub-Commission on Prevention of Discrimination and Protection of Minorities a preliminary report and three progress reports before presenting his final report, published in 1999. ${ }^{12}$ Several extracts from his final report are worth noting in this context:

$104 \ldots$ the main finding that emerges ... relates to the widespread recognition of 'overseas peoples' - including indigenous peoples in the current sense of the term - as sovereign entities by European powers and their successors, at least during the era of the Law of Nations.

105. Consequently, the problematique of indigenous treaties and other juridical instruments today affecting the lives of these peoples, hinges on what the Special Rapporteur has termed a process of retrogression, by which they have been deprived of (or saw greatly reduced) three of

\footnotetext{
${ }^{9}$ Anaya 1996. $\quad{ }^{10}$ The American Society of International Law 1984. $\quad{ }^{12}$ Alphonso Martinez 1999.

${ }^{11}$ Martinez Cobo 1986: para 379.
} 
the four essential attributes on which their original status as sovereign nations was grounded, namely their territory, their recognized capacity to enter into international agreements, and their specific forms of government ... Not to mention the substantial reduction of their respective populations in many countries around the world, due to a number of factors including, assimilationist policies. $\cdots$

110. In establishing formal legal relationships with peoples overseas, the European parties were clearly aware that they were negotiating and entering into contractual relations with sovereign nations, with all the international legal implications of that term during the period under consideration.

111. This remains true independently of the predominance, nowadays, of more restricted State-promoted notions of indigenous 'selfgovernment', 'autonomy', 'nationhood' and 'partnership' - if only because the 'legitimization' of their colonization and trade interests made it imperative for European powers to recognize indigenous nations as sovereign entities.

112. In the course of history, the newcomers then nevertheless attempted to divest indigenous peoples ... of their sovereign attributes, especially jurisdiction over their lands, recognition of their forms of social organization, and their status as subjects of international law.

123. Closer scrutiny of the provisions of treaties concluded between indigenous peoples and States also reveals that in most cases the subject of such treaties is common in international law, whatever the historical period considered: thus such treaties deal with questions of war/peace, trade provisions, protection of the subjects/citizens of each signatory party, and so forth.

The Special Rapporteur expanded on these comments in Part III of his final report:

$186 \ldots$ something must be said about the juridical instruments that emerged after the initial contacts in the various periods. Their intrinsic nature, form and content make it clear that the indigenous and non-indigenous parties mutually bestowed on each other (in either an explicit or implicit manner) the condition of sovereign entities in accordance with the non-indigenous international law of the time.

187. It must be stressed that certain States had a very powerful motivation for making these treaties or other international instruments of a contractual nature requiring the consent of participants. Furthermore, this motivation (in the direct interest of the non-indigenous party) was quite clear: to legitimize (via the acquiescence of the autocthonous sovereign of the territories in question) any 'right' (real or intended) with which they could counter opposing claims advanced by other colonial powers vying for control of those lands. 
188. However, to acquire such 'rights' via derivative title (since they clearly lacked original title, or because the legality of their presence in those areas was being questioned), required that they seek the agreement of the legitimate holder of the original title, i.e., the indigenous nation in question. The latter would have to do this by the formal cession of their lands (or their sale, or a concession of acquisitive possession or any other type of valid transfer).

189. In accordance with European legal tradition and formalities, this transfer should appear in a document that could be presented as proof before the colonizing power's equals in the 'concert of civilized nations'. The ideal instrument for this, according to the international law of the epoch, was the treaty. Furthermore, the only entities with the juridical capacity to make treaties were (like today), precisely, international subjects possessing sovereignty - their own or delegated by other sovereigns - through the exercise of it.

190. In a second phase of the colonization project and until it peaked - during its 'classical' manifestation or a variation thereof, and especially as of the second third of the nineteenth century - there was a visible increase in the use of military force to acquire vast tracts of 'new' territories. This shift was very much in line with the enormous power already being wielded by the traditional European imperial powers and by others who emerged later to begin their own expansionism.

191. The newcomers' descendants increased their military and economic capacity. That of the indigenous peoples remained (in the best of cases) the same or (most frequently) decreased rapidly, which resulted in both cases in a growing vulnerability of these peoples to the machinations of the non-indigenous, with whom they had possibly made treaties/agreements, but who now wished to ignore their sovereignty and impose a 'new order' on their ancestral homes.

192. Thus began the process that the Special Rapporteur has preferred to call (without any claim to originality) the 'domestication' of the 'indigenous question', that is to say, the process by which the entire problematique_was removed from the sphere of international law and placed squarely under the exclusive competence of the internal jurisdiction of the non-indigenous States. In particular, although not exclusively, this applied to everything related to juridical documents already agreed to (or negotiated later) by the original colonizer States and/or their successors and indigenous peoples. ${ }^{13}$

Alfonso Martinez also considered agreements which were not designated as treaties, and other 'constructive arrangements' which achieved similar ends, as well as situations where no such measures had been adopted, such as Australia. In his Part IV Conclusions he wrote:

\footnotetext{
${ }^{13}$ Alphonso Martinez 1999.
} 
262. He also has reasons to conclude that there is a widespread desire on the indigenous side to establish (or re-establish) a solid, new, and different kind of relationship, quite unlike the almost constantly adversarial, often acrimonious relationship it has had until now with the non-indigenous sector of society in the countries where they coexist. In the view of the indigenous peoples, this can only be achieved either by the full implementation of the existing mutually agreed-upon legal documents governing that relationship (and a common construction of their provisions), or by new instruments negotiated with their full participation. This perception is shared by the appropriate government officials in a number of countries, including Canada, New Zealand and Guatemala.

263. Finally, the Special Rapporteur is strongly convinced that the process of negotiation and seeking consent inherent in treaty-making (in the broadest sense) is the most suitable way not only of securing an effective indigenous contribution to any effort towards the eventual recognition or restitution of their rights and freedoms, but also of establishing much needed practical mechanisms to facilitate the realization and implementation of their ancestral rights and those enshrined in national and international texts. It is thus the most appropriate way to approach conflict resolution of indigenous issues at all levels with indigenous free and educated consent. ${ }^{14}$

The Special Rapporteur went on to recommend new mechanisms within States to ensure compliance with treaties and agreements, with possible back-up from an international body.

\section{Human Rights law}

The references by Miguel Alfonso Martinez to human rights take us beyond classical International Law references to 'States', 'sovereignty' and 'treaties' to modern human rights standards. Of course the Charter of the United Nations gives primacy to the place of States, to the 'sovereign equality of all its Members', ${ }^{15}$ and affirms that nothing in the Charter 'shall authorise the United Nations to intervene in matters which are essentially within the domestic jurisdiction of any state' (subject to possible enforcement measures under Chapter VII of the Charter). ${ }^{16}$

But Article 1 includes among the purposes of the UN, along with the maintenance of international peace and security, ${ }^{17}$ that of 'develop[ing] friendly relations among nations based on respect for the principle of equal rights and self-determination of peoples, ${ }^{18}$ and it refers to 'promoting and encouraging respect for human rights and for fundamental freedoms for all without distinction as to race, sex, language, or religion'. ${ }^{19}$ So peace and security among States is seen as integrally connected with the rights of people, and of peoples.

These concepts have been defined and developed in the evolution of International Human Rights Law, particularly the half dozen core treaties, and some influential Declarations. The International Covenant on Civil and Political Rights is perhaps the most significant for present

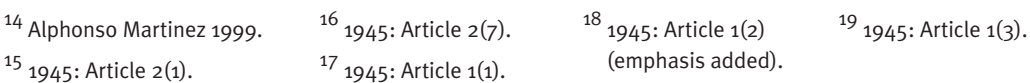


purposes in relation to the notion of a treaty or agreement between a State and Indigenous peoples within that State.

Article 1

1. All peoples have the right of self-determination. By virtue of that right they freely determine their political status and freely pursue their economic, social and cultural development. ${ }^{20}$

\section{Self-determination}

The concept of 'self-determination of peoples' has been developed most clearly in relation to the peoples of colonial possessions of European powers across the seas. This took the form of the 'decolonisation' process that witnessed the break-up of empires, and the accession to independence and Statehood of most of the former, distant components of those empires. What has been more problematic has been the possible application of the principle of selfdetermination to minorities within the boundaries of States and to Indigenous peoples. ${ }^{21}$

Of course, self-determination refers to a process. The particular outcome of that process need not be secession to independent Statehood. In 1970 the General Assembly adopted Res 2625 (xxv), Declaration on Principles of International Law Concerning Friendly Relations and Cooperation among States in Accordance with the Charter of the United Nations. ${ }^{22}$ It states that other modes of implementing the right of self-determination of peoples may be 'free association' with an independent state or 'any other political status freely determined by a people'.

Sarah Pritchard writes that,

... self-determination is a technique or method, a continuum of rights, a plethora of possible solutions, rather than an absolute right to full external self-determination in the form of complete independence. It encompasses a range of alternatives to independent statehood, including associated statehood, internationalised territories, federal schemes, autonomy, ethnic, linguistic and religious minority rights to ensure the continued integrity of a people, guarantees of nondiscrimination and integration. The basic requirement is a procedure - a freely made choice and the possibility to reconsider arrangements after a suitable interval. ${ }^{23}$

Paragraph 7 of the Friendly Relations Declaration addressed the critical question of the relationship between the right of self-determination, on the one hand, and the principles of territorial integrity and national unity, on the other. The territorial integrity of an existing State is given the preferred position, but this is conditional: such territorial integrity is inviolable only in respect of those States 'conducting themselves in compliance with the principle of equal rights and self-determination of peoples ... and thus possessed of a government representing the whole people belonging to the territory without distinction as to race, creed, or colour'. So a discriminatory denial of human rights to a people, or a failure to allow them adequate representation in government or adequate participation in decisions affecting them, may forfeit the right of a State to deny to such a people a right of self-determination which might include

\footnotetext{
${ }^{20}$ The identical language appears in Article $1(1)$ of the

${ }^{22}$ The Declaration is known, for short, as the UN Friendly International Covenant on Economic, Social and Cultural Rights 1966. Relations Declaration.

${ }^{21}$ See, generally, Steiner and Alston 2000: chapter 15

${ }^{23}$ Pritchard 1998: chapter 6, part B: para [66].
} 
the option of secession. However there are no mechanisms available under International Law to make such a right a reality, other than in the limited range of situations that may precipitate Security Council action under Chapter VII of the Charter.

\section{Indigenous peoples? Or Indigenous populations?}

Because of sensitivities of States to the issue of who constitutes a 'people' such as to be entitled to self-determination, the Martinez Cobo study employed the term 'Indigenous Populations', and the same term was used when the UN's Sub-Commission on Prevention of Discrimination and Protection of Minorities was authorised to establish its Working Group on Indigenous Populations. When the International Labour Organization revised its 1957 Convention No 107, which also employed the term 'populations', Indigenous representatives urged it to use the term 'peoples' instead. It eventually did so, in its 1989 Convention Concerning Indigenous and Tribal Peoples in Independent Countries, but subject to the express qualification in Article 1 (3) of the ILO Convention No. 169 that the use of the term 'shall not be construed as having any implications as regards the rights which may attach to the term under international law'.

\section{The UN Draft Declaration on the Rights of Indigenous Peoples}

The UN Working Group on Indigenous Populations, in consultation with (among others) representatives of Indigenous peoples from around the world, eventually completed the drafting of the Draft Declaration on the Rights of Indigenous Peoples in 1993. It was referred to the parent Sub-Commission on Prevention of Discrimination and Protection of Minorities. The Sub-Commission referred it straight up the line to the Commission on Human Rights which, unlike the Sub-Commission and its Working Group, is made up from representatives of governments. That body established its own open-ended Working Group to meet in separate sessions to deliberate on the language of the Draft Declaration. Progress has been slow, and a major sticking point has been the provisions in the Draft Declaration relating to the political rights of Indigenous peoples.

Article 3 of the Draft Declaration simply replicates the language of Article 1(1) of the two Covenants:

3. Indigenous peoples have the right of self-determination. By virtue of that right they freely determine their political status and freely pursue their economic, social and cultural development.

Other provisions of the Draft Declaration deal with aspects of self-determination, notably Article 31 which reads:

Indigenous peoples, as a specific form of exercising their right to self-determination, have the right to autonomy or self-government in matters relating to their internal and local affairs, including culture, religion, education, information, media, health, housing, employment, social welfare, economic activities, land and resources management, environment and entry by nonmembers, as well as ways and means for financing these autonomous functions.

Other provisions refer to determination of membership (citizenship) and the right to maintain laws, structures, institutions etc. Some provisions deal with rights of public participation. ${ }^{24}$

\footnotetext{
${ }^{24}$ Nettheim et al 2002: chapter 2.
} 
The Draft Declaration is 'soft law', and even if accepted by the Commission on Human Rights and, ultimately, by the General Assembly, will remain 'soft law', with no binding force in International Law. But its provisions relating to the political rights of Indigenous peoples find counterparts in an increasing number of other elements of International Law.

The broader issues of self-determination as to the political status of an Indigenous people would appropriately be settled by an agreement or agreements between the people and the State. Whether such an agreement is called a treaty or something else is a matter of choice.

\section{Treaty proposals in Australia}

When the National Aboriginal Conference, in 1979, floated the idea of a latter-day treaty, Prime Minister Fraser objected to the word. Discussion proceeded instead about a 'Makarrata' (a Yolgnu word). In 1987 Prime Minister Hawke revived the idea of a treaty to settle outstanding issues, but the idea did not proceed beyond 1988. At that time, Mr Howard, as Opposition leader, again opposed the notion of anything called a 'treaty'.

In 1983 the Senate Standing Committee on Constitutional and Legal Affairs produced a valuable report called 'Two Hundred Years Later - A Report on the Feasibility of a Compact or 'Makarrata' between the Commonwealth and Aboriginal People'. The Committee's conclusion was that such a compact was feasible, and it also reported on how such a document might be given Constitutional status. The issue was revisited in the 1988 Final Report of the Constitutional Commission. The Commission made no recommendation, pending the actual negotiation of an agreement.

What support is there from Aborigines and Torres Strait Islanders for an Australian agreement?

In 1994-95 national bodies consulted and prepared reports for the Commonwealth Government on the then-mooted 'social justice package'. The Aboriginal and Torres Strait Islander Commission (ATSIC) found continuing Indigenous support for the concept of a negotiated overall settlement 'underpinned by regional agreements'. It proposed initial development of a framework agreement for the negotiation process. The Council for Aboriginal Reconciliation (CAR) also gave some support to the idea.

The idea of a treaty went off the agenda after the election of the Coalition Government in early 1996, and was revived largely at the time of the 'Corroboree 2000' event in Sydney in May 2000. That was the occasion on which the Council for Aboriginal Reconciliation formally presented the documents on which it had been working. The Australian declaration towards reconciliation is largely aspirational. ${ }^{25}$ It was accompanied by a document entitled Roadmap for Reconciliation which comprised four National Strategies to Advance Reconciliation:

The National Strategy to Sustain the Reconciliation Process;

The National Strategy to Promote Recognition of Aboriginal and

Torres Strait Islander Rights;

The National Strategy to Overcome Disadvantage; and

The National Strategy for Economic Independence. ${ }^{26}$

\footnotetext{
${ }^{25}$ CAR 2000a. ${ }^{26}$ CAR 200ob.
} 
In December 2000 the Council for Aboriginal Reconciliation presented its Final Report, RECONCILIATION. Australia's challenge, to political leaders gathered in Parliament House, Canberra. In chapter 10, the Council made six recommendations, two of which are relevant to the current discussion:

5. Each government and parliament:

- recognise that this island and its waters were settled as colonies without treaty or consent and that to advance reconciliation it would be most desirable if there were agreements or treaties; and

- negotiate a process through which this might be achieved that protects the political, legal, cultural and economic position of Aborigines and Torres Strait Islander peoples.

6. That the Commonwealth Parliament enact legislation (for which the Council has provided a draft in this report) to put in place a process which will unite all Australians by way of an agreement, or treaty, through which unresolved issues of reconciliation can be resolved.

ATSIC consulted with Indigenous people around Australia after Corroboree 2000 to ascertain whether there was support for pursuing the idea. It established a National Treaty Support Group and a National Treaty Secretariat. ${ }^{27}$

\section{Summary}

1. At the time of European takeover of distant lands in the Americas and the Pacific, the assumption was that the consent of the existing inhabitants was required. The British employed the term 'treaty' for this purpose. The underlying proposition was that there was a consensual agreement between juridical equals.

2. The English word 'treaty' has come to be confined only recently to connote a formal agreement between two or more sovereign States.

3. The term 'State' has also been formally defined only in recent times. Many at least of the Indigenous peoples concerned would have qualified as 'States', even within this restricted definition, at the time of colonisation. Hence, the word 'treaty', even in its modern sense, would have been appropriate.

4. When (under such treaties, or without treaty) a European nation established 'sovereignty' over the territories of prior inhabitants, those peoples became subordinated to the colonial power in terms of the State-centred system of international relations and international law. It was in the interest of the Imperial powers to 'domesticate' the status of the Indigenous peoples.

5. But US law has long acknowledged that Native Americans retain a residual 'sovereignty', even if subject to Congress, and there remain, on Indian country, systems of tribal governments and tribal courts. Canada recognises the inherent right of First Nations to self-government, and continues to negotiate treaties with them. Other States (e.g., New Zealand, Denmark, Norway) also acknowledge Indigenous political rights.

\footnotetext{
${ }^{27}$ www.treatynow.org See also ATSIC and AIATSIS 2003. For a recent study and update on the treaty debate, see Brennan et al 2005.
} 
6. The nineteenth-century push to 'domesticate' the status of Indigenous peoples has been countered in recent decades by a restoration of their status as subjects of International law. This is evidenced in a growing number of 'treaties, agreements and other constructive arrangements between States and indigenous populations', as reported by Special Rapporteur Miguel Alfonso Martinez.

7. The restoration of the status of Indigenous peoples as subjects of International law is evidenced also in a number of multilateral instruments. Some relate solely to Indigenous peoples (eg, the UN Draft Declaration on the Rights of Indigenous Peoples, ILO Convention No. 169). Others are of general application but make specific reference to Indigenous peoples (eg, Convention on the Rights of the Child, and a number of instruments relating to such matters as the environment, trade and finance, and multilateral lending institutions). Human rights treaties of general application have, through their respective expert monitoring committees, acquired a developing 'jurisprudence' which applies their standards to the specific situations of Indigenous peoples. And the UN itself has developed special mechanisms in relation to Indigenous peoples, notably the Working Group on Indigenous Populations. In 2002 in New York, there was held the inaugural meeting of a new mechanism - the Permanent Forum on Indigenous Issues, comprising eight experts nominated by States and eight representatives of Indigenous peoples from the various regions.

If, in the latter part of the nineteenth century, the status of Indigenous peoples had been 'domesticated', they have once again resumed their earlier status as subjects of International Law. The concept of 'treaty', to govern the fundamentals of their relationship with the State, seems as appropriate today as it was in previous times.

\section{The content of a treaty ${ }^{28}$}

We have a relatively clear picture of the matters that are important to Aboriginal and Torres Strait Islander peoples today as 'unfinished business', thanks to a number of public inquiries, public debates, and Indigenous reports and statements.

\section{Public inquiries and public debates}

We have known since the 1960s that Aboriginal and Torres Strait Islander peoples have been seriously over-represented in the criminal justice and juvenile justice systems. ${ }^{29}$ One initial response was the establishment of the Aboriginal Legal Services (ALSs). ${ }^{30}$ The ALSs have been important, and continue to be important. But over-representation continues, as evidenced in the 1991 National Report of the Royal Commission into Aboriginal Deaths in Custody. ${ }^{31}$ The Royal Commission offered 339 recommendations, almost all of which were accepted by governments, at least in principle - but subsequent analyses show that implementation has been limited, and the statistics of over-representation remain. ${ }^{32}$

We have also known since the 1960s that land rights is of central importance to Indigenous Australians. And responses through legislation and court decisions have been reasonably substantial. There are particular problems in working out the proper approach to native title

\footnotetext{
${ }^{28}$ The following discussion draws partly from Nettheim 2001, and LIAC 2001. It is also partly incorporated in McRae et al 2003.

${ }^{29}$ Eggleston 1976 (based on her Ph D thesis commenced in 1965), followed by other studies by other scholars, plus public inquiries.

${ }^{30}$ It was also a response to cultural and other problems that Indigenous Australians experienced in getting assistance
}

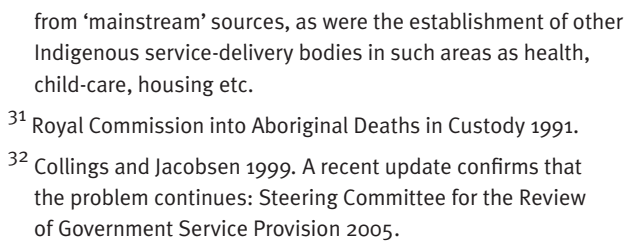

from 'mainstream' sources, as were the establishment of other Indigenous service-delivery bodies in such areas as health, child-care, housing etc.

${ }^{31}$ Royal Commission into Aboriginal Deaths in Custody 1991.

${ }^{32}$ Collings and Jacobsen 1999. A recent update confirms that the problem continues: Steering Committee for the Review of Government Service Provision 2005. 
cases, and to meeting the aspirations of people whose country is no longer available for return. And there are serious problems with the 1998 amendments to the Native Title Act 1993 (Cth). ${ }^{33}$

We have also learned something of the importance of cultural matters, particularly in relation to sites, though some scepticism seems still to surround these matters - witness the saga of the Hindmarsh Island Bridge. There is less awareness about the idea for a continuing role for Indigenous laws, and of the need to adjust Australian laws to accommodate Indigenous law.

There is wide recognition of the historical fact that many Indigenous Australians were removed as children from their families, and that such removal has caused pain and suffering for many of them, and for the families from which they were removed. ${ }^{34}$ But there is considerable division as to how - and whether - the nation should respond.

There is little comprehension about claims for self-determination or self-government, that is, the claims of people to be allowed to decide matters of importance to them, and their claims to be full participants in decisions by other levels of government that affect them.

There is perhaps least comprehension about the notion that there are constitutional matters that need to be addressed in the gaining of belated consent to the non-Indigenous takeover of Australia.

\section{The 'Social Justice package'}

The Keating Government proposed a three-stage response to the Mabo decision. Stage 1 was the Native Title Act 1993 (Cth). Stage 2 involved the establishment of the Land Fund and the Indigenous Land Corporation. Stage 3 was a proposal to address the non-land needs and aspirations of Indigenous Australians. For the purposes of Stage 3, the Government asked ATSIC and the Council for Aboriginal Reconciliation to consult widely so as to identify those needs and aspirations and to recommend how they might be addressed. Both bodies produced reports during 1995, and so did the Aboriginal and Torres Strait Islander Social Justice Commissioner in the Human Rights and Equal Opportunity Commission (HREOC). ${ }^{35}$

ATSIC drafted Principles for Indigenous Social Justice which were designed 'to guide all future relationships between the Commonwealth and indigenous peoples'. They would require Commonwealth acceptance of the fundamental rights of Aboriginal and Torres Strait Islander peoples to:

a. recognition of indigenous peoples as the original owners of this land, and of the particular rights that are associated with that status;

b. the enjoyment of, and protection for, the unique, rich and diverse indigenous cultures;

c. self-determination to decide within the broad context of Australian society the priorities and the directions of their own lives, and to freely determine their own affairs;

d. social justice and full equality of treatment, free from racism; and

e. exercise and enjoy the full benefits and protection of international covenants. ${ }^{36}$

\footnotetext{
${ }^{33}$ The Aboriginal and Torres Strait Islander Social Justice $\quad{ }^{34}$ HREOC 1997

Commissioner has continued his scrutiny of these issues in his 35 See ATSIC 1995; CAR1995; Aboriginal and Torres Strait

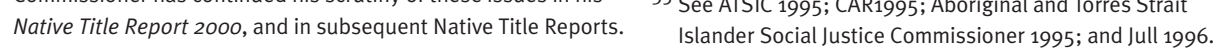

${ }^{36}$ ATSIC 1995: 10.
} 
The Council for Aboriginal Reconciliation also stressed the issue of socio-economic disadvantage, and referred to such matters as 'citizenship rights'. It distinguished these individual equality rights from 'Indigenous rights' - the collective and distinctive rights of Indigenous peoples to land and waters, culture, and so on. ${ }^{37}$

These categorisations of Indigenous rights are reflected at the international level in the Draft Declaration on the Rights of Indigenous Peoples, ${ }^{38}$ currently under consideration in the United Nations' Commission on Human Rights. These claims/rights in respect of non-discrimination, territory, political rights and culture find support not only in the Draft Declaration but in a number of international treaties and other instruments, most of which have been ratified by Australia. ${ }^{39}$ The Council for Aboriginal Reconciliation's four National Strategies also largely match these formulations. ${ }^{40}$

\section{Focus 2000}

In September 1999 ATSIC convened a meeting of some 60 Indigenous leaders to discuss future developments. The meeting produced a list of items of 'unfinished business' as a Statement on Indigenous Rights ${ }^{41}$ which the leaders seek to have embodied in an agreement with governments. The list of matters is as follows:

- Equality

- Distinct characteristics and identity

- Self-determination

- Law

- Culture

- Spiritual and religious traditions

- Language

- Participation and partnerships

- Economic and social development

- Special measures

- Education and training

- Land and resources

- Self-government

- Constitutional recognition

- Treaties and agreements

- Ongoing processes

If this is accepted as the list of 'unfinished business', it represents also the specific issues that need to be resolved in achieving reconciliation, and specific items which people may seek to address through negotiation of a 'treaty'. I group them as Citizenship or Equality Rights, on the one hand, and Indigenous Rights, on the other; and I group the Indigenous Rights under the headings of territorial rights, cultural rights and political rights. In addition I make references to selected International human rights standards relevant to these issues. The references are intended to be illustrative only: space does not permit an exhaustive analysis.

37 CAR 1995: 22, 26-7.

38 1993, UN Doc E/CN.4/Sub.2/1993/26. In the latter part of 2005 the Commission on Human Rights was replaced by a new Human Rights Council which, in mid-2006, accepted the Draft Declaration as embodied in the 'Chairman's Text'. It now awaits consideration by the General Assembly.
39 See Nettheim 2001b; and Pritchard and Heindow-Dolman 1998: 3.

${ }^{\circ 0}$ CAR 200ob.

${ }^{41}$ Reproduced in P Dodson 1999: 270-3. 


\section{Equality/citizenship rights \\ Equality}

The need here is not only to overcome overt racial discrimination. Such discrimination clearly continues. But it no longer has an express legislative basis. And Australia has fairly sophisticated anti-discrimination legislation and machinery at Commonwealth and State/Territory levels which, with some fine tuning, should be able to deal with the more blatant cases. ${ }^{42}$

At the level of International law, both the International Covenant on Civil and Political Rights (ICCPR) ${ }^{43}$ Article 2(1) and the International Covenant on Economic, Social and Cultural Rights ${ }^{44}$ (ICESCR) Article 2(2) stress that the respective rights are to be enjoyed without discrimination on the basis of race, and other grounds. The International Convention on the Elimination of All Forms of Racial Discrimination (ICERD) ${ }^{45}$ deals specifically, and in more detail, with discrimination on the basis of race, and provides the basis, through Constitution s.51 (xxix), 'external affairs', for the validity of the Racial Discrimination Act 1975 (Cth).

The need is also for what have been referred to as 'citizenship rights' - the rights of Indigenous Australians to comparable levels of services as are available to other Australians, and the progressive reduction of the marked disparities in the socio-economic indicators in such matters as health, housing, education and employment. Such disparities are matters of concern in terms of Australia being a party to the International Covenant on Economic, Social and Cultural Rights. They are the focus for the Council for Aboriginal Reconciliation's National Strategy to Overcome Disadvantage. ${ }^{46}$ They receive detailed consideration in chapter 4 of the Aboriginal and Torres Strait Islander Social Justice Commissioner's Social Justice Report 2000. ${ }^{47}$

\section{Special measures}

But would special programmes to overcome such disadvantages themselves offend the ideal of equality? This notion, 'the myth of equality', was one of the reasons suggested by Brennan and Crawford for the lack of progress in attending to the aspirations of Indigenous Australians. ${ }^{48}$ It remains politically potent in the One Nation party's attack on the 'special privileges' accorded to Indigenous Australians. ${ }^{49}$

But, as Brennan and Crawford observe, the jurisprudence of comparable countries such as the USA and Canada, and of Australia itself, accepts that 'special measures' to overcome disadvantage do not offend principles of equality. The International Convention on the Elimination of all Forms of Racial Discrimination expressly permits 'special measures' to overcome disadvantage ${ }^{50}$ and even requires State parties to adopt such measures. ${ }^{51}$ The Convention is implemented in Australian law by the Racial Discrimination Act 1975, section 8(1) of which permits such 'special measures' as exceptions to the prohibition of discrimination.

On a broader view, the sort of measures under discussion do not constitute discrimination in the first place, so as to require authorisation as an exception. Differentiation as such does not constitute discrimination, and the goal of equality is less concerned with formal equality of treatment than with substantive equality of outcomes. ${ }^{52}$

\footnotetext{
$4^{2}$ For an important assessment of the Commonwealth legislation, see Race Discrimination Commissioner 1995.

43 1966, 999 UNTS 171.

44 1966, 99 UNTS 3.

45 1966, 660 UNTS 195.
}

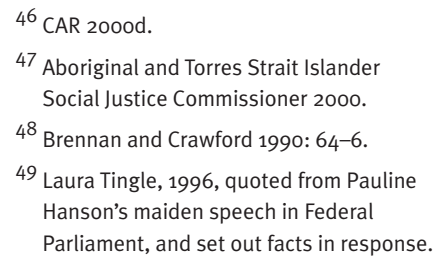

47 Aboriginal and Torres Strait Islander Social Justice Commissioner 2000.

${ }^{48}$ Brennan and Crawford 1990: 64-6.

49 Laura Tingle, 1996, quoted from Pauline Hanson's maiden speech in Federal Parliament, and set out facts in response.

50 1966, 660 UNTS 195: Article 1(4).

${ }^{51}$ 1966, 660 UNTS 195: Article 2(2).

52 Race Discrimination Commissioner 1995, chapter 9; McRae et al 2003: 448-50. For other discussion of these issues, see Aboriginal and Torres Strait Islander Social Justice Commissioner 2001: chapter 1. 


\section{Education and training}

Education and training are obviously an essential component of the equality agenda. Statistics continue to indicate that Indigenous Australians have markedly lower levels of education and training than the level of attainment for Australians generally. Education and training are also important to many of the other items on the list of 'unfinished business'.

These matters are dealt with in some detail in ICESCR Article 6 (2) and, especially, Articles 13 and 14 . Such rights are to be exercised without discrimination of any kind as to race, etc. (Article 2(2)).

\section{Economic and social development}

This agenda item also links to the matter of overcoming disadvantage. The Council for Aboriginal Reconciliation's Roadmap for Reconciliation has a distinct National Strategy for Economic Independence which is directed to achieving, for Aboriginal and Torres Strait Islander peoples and communities, 'the same levels of economic independence as the wider community'. The Strategy lists essential actions as including access to jobs and resources, effective business practices and skills development. Article 6 and other Articles in ICESCR are relevant to these goals.

\section{Participation and partnerships}

This item links to both goals of overcoming disadvantage and economic empowerment by proposing partnerships with business and other private sector bodies.

The idea of partnership also links into the role of governments, particularly in relation to the delivery of services to Indigenous peoples and communities. So does the term 'participation'. I have referred to areas where such participation and partnership have been important, namely the establishment and funding of Aboriginal Legal Services, Aboriginal Medical Services, and so on.

Participation also has a wider reference to the notion that Indigenous peoples should be effective participants when governments and public authorities make decisions on matters that particularly affect Aborigines and Torres Strait Islanders. ${ }^{53}$ This notion of public participation takes us into the area of Indigenous political rights, discussed below.

\section{Indigenous rights}

The Council for Aboriginal Reconciliation's Roadmap for Reconciliation has a distinct National Strategy to Promote Recognition of Aboriginal and Torres Strait Islander Rights which addresses a number of the distinctive Indigenous rights in relation to territorial, cultural and political rights.

\section{Territorial rights}

\section{Land and resources}

The question of land rights and native title has been at the forefront of the demands of Aboriginal and Torres Strait Islander peoples on the Australian legal and political systems. There has been widespread acceptance of the case for recognising the continuing relationship of Indigenous peoples with land and waters where this can be achieved without displacing post-colonisation titles or public uses of land - and without unduly impeding 'resource development' activities,

\footnotetext{
53 Aboriginal and Torres Strait Islander Social Justice Commissioner 2000: chapter 4.
} 
such as mining. There is also widespread acceptance of the fact that 'country' is central to Aboriginal cultures.

These matters find support in International human rights law through ICERD, Article 5, according to which States parties undertake to guarantee the right of everyone, without distinction as to race (etc), to equality before the law, 'notably in the enjoyment of the following rights', including:

(d)(v) The right to own property alone as well as in association with others;

(vi) The right to inherit. ${ }^{54}$

They also find support in other instruments such as ILO Convention No. 169, Articles $13-15$.

\section{Cultural rights}

\section{Distinct characteristics and identity}

Aboriginal peoples and Torres Strait Islanders have histories and cultures which are distinct from those of other Australians. Of course, many people of Indigenous descent live as part of the broader society and may have little or no knowledge of their Indigenous heritages. But for those who retain connections to their heritage, their claim is more wide-ranging than the claims of immigrant ethnic groups to multiculturalism. It is a claim to recognition of their distinct characteristics and identity as the First Peoples of Australia. It commences with territorial rights, which are central to culture, but goes beyond territory, particularly when territory cannot be regained. These aspirations receive some recognition in ILO Convention No. 169, Articles 2 and 5, and elsewhere.

\section{Culture}

Culture has many dimensions, some of which are indicated by separate items on the list of 'unfinished business'. It includes art and ceremony, it includes knowledge of the properties of plants, and a range of other matters which receive inadequate protection under Australian law. ${ }^{55}$

Article 27 of the ICCPR has proved to be significant for Indigenous peoples, even though its primary focus is minorities:

In those States in which ethnic, religious or linguistic minorities exist, persons belonging to such minorities shall not be denied the right, in community with the other members of their group, to enjoy their own culture, to profess and practise their own religion, or to use their own language..$^{56}$

This provision is relevant to the following two items, as well. A number of other instruments are also relevant.

\footnotetext{
54 See Mabo v Queensland (Mabo (No. 1)) (1988) 166 CLR 186. See also CERD general recommendation XXIII(51) (18 August 1997) paras 3-5, set out in (1998) Australian Indigenous Law Reporter 142 .
}

55 An analysis of the shortcomings of Australian law to protect Indigenous intellectual and cultural property can be found in a report prepared by Indigenous lawyer, Terri Janke, for AIATSIS and ATSIC: Janke 1998. For a shorter account, see Janke 1999.

56 1966, 999 UNTS 171. 


\section{Spiritual and religious traditions}

These matters are very important to Indigenous Australians. They receive some support from the protection provided for sites and objects by Commonwealth and State/Territory laws. But there have been weaknesses in those laws, ${ }^{57}$ and 1998 draft Commonwealth legislation was seen by many - including the Senate - as further weakening protection at national level. ${ }^{58}$ The Hindmarsh Island Bridge Act 1997 (Cth) placed the area in question outside the protection of the 1984 Commonwealth Act, ${ }^{59}$ and its validity was upheld by a High Court majority. ${ }^{60}$

ICESCR Article 5 provides for equality before the law in the enjoyment of (among other rights) 'd)(vii) The right to freedom of thought, conscience and religion'. ICCPR Article 18 makes more detailed provision concerning these rights.

\section{Language}

This item on the list of 'unfinished business' is largely self-explanatory. Aboriginal people are no longer forbidden to speak their languages, though many have lost their languages, and many languages have themselves been lost. Problems still arise. For example, until quite recently in Northern Territory courts, interpreters were available for a number of languages, but not for Aboriginal languages.

ICCPR Article 14 (3)(f) requires the free use of an interpreter for defendants in criminal proceedings. More broadly, Article 27 provides that minorities shall not be denied the right to use their own language.

\section{Law}

Some legislation has recognised Indigenous law in particular matters, such as recognition of traditional marriages, or hunting and fishing rights. Some courts have been able to provide recognition of some aspects of Indigenous laws. Considerable work was done by the Australian Law Reform Commission on the overall situation in its 1986 report ${ }^{61}$ but most of the recommendations have not been implemented. ${ }^{62}$

ILO Convention No. 169, Article 8, provides:

1. In applying national laws and regulations to the peoples concerned, due regard shall be had to their customs or customary laws.

2. These peoples shall have the right to retain their own customs and institutions, where these are not incompatible with fundamental rights defined by the national legal system and with internationally recognized human rights. Procedures shall be established, whenever necessary, to resolve conflicts which may arise in the application of this principle.

3. The application of paragraphs 1 and 2 of this Article shall not prevent members of these peoples from exercising the rights granted to all citizens and from assuming the corresponding duties.

\footnotetext{
57 Evatt 1996, 1998.

${ }^{58}$ Aboriginal and Torres Strait Islander Social Justice Commissioner 2001: 135-48.

${ }^{59}$ Aboriginal and Torres Strait Islander Heritage

${ }^{60}$ Kartinyeri v Commonwealth (1998) 195 CLR 337.

${ }^{61}$ Australian Law Reform Commission 1986.

${ }^{62}$ McRae et al 1997: chapter 2. 


\section{Political rights \\ Self-government}

The starting point, of course, is that the various Aboriginal and Torres Strait Islander peoples governed themselves prior to colonisation. It is possible to express this self-government in terms of an original 'sovereignty'. Indeed, US law acknowledges the continuing sovereignty of Indian nations, though subject to the ultimate sovereignty of Congress, and Indian nations have their own tribal governments and tribal courts. ${ }^{63}$ In Canada, the term 'sovereignty' has largely been avoided in relation to First Nations peoples, but there is increasing recognition of their 'inherent right to self-government'. The issue has been discussed in Australia over recent decades, and it is possible to identify some instances of effective self-government on particular matters. But it would be fair to say that the notion is unfamiliar to most Australians. ${ }^{64}$

\section{Self-determination}

This concept derives from several references in the Charter of the United Nations and the express language of Article 1 of both Covenants - the International Covenant on Civil and Political Rights and the International Covenant on Economic, Social and Cultural Rights, as discussed above. Australia has, in the past, supported the use of similar language in the debates on the UN Draft Declaration on the Rights of Indigenous Peoples, but has more recently spoken against use of the term. ${ }^{65}$

Effectively, the concept of self-determination is one that asserts the right of 'a people' to decide its political status. Indigenous Australians argue that, in the absence of an initial treaty or treaties, they have never been able to exercise this right, but that the right still exists. The point relates to the earlier discussion about entry to the Australian polity, and to the debate about a modern treaty. ${ }^{66}$

\section{Constitutional recognition}

Various proposals for constitutional change in relation to Indigenous Australians have been put forward over the years. ${ }^{67}$ The Council for Aboriginal Reconciliation's National Strategy to Promote Recognition of Aboriginal and Torres Strait Islander Rights contains three proposals relating to the Australian Constitution: first, a new preamble which recognises the status of the first Australians; second, a repeal of s.25, which refers to the possibility that persons of any race might be denied the vote under State law; and third, a general prohibition of discrimination on the basis of race. These proposals were incorporated in Recommendation 3 in the Council's Final Report. ${ }^{68}$

It is not easy to locate a provision in an International instrument which expressly requires constitutional recognition of Indigenous rights. But ICCPR, Article 2, for example, requires States parties to make effective provision for the protection of the enumerated rights, without discrimination, through legislative measures where appropriate, and to provide for enforceable remedies for breach. Australia did implement its principal obligations under ICERD through enactment of the Racial Discrimination Act 1975 (Cth). But, as an ordinary statute of the Commonwealth Parliament, it can be displaced or repealed (in whole or in part) by a subsequent Commonwealth Act to the extent of any inconsistency. ${ }^{69}$

\footnotetext{
63 Brennan 1999: 623 .

${ }^{64}$ See, generally, McRae et al 2003: chapter 3; Nettheim 1993; Webber 1999; Pritchard 1999: 609-10.

65 Dodson and Pritchard 1998.
}

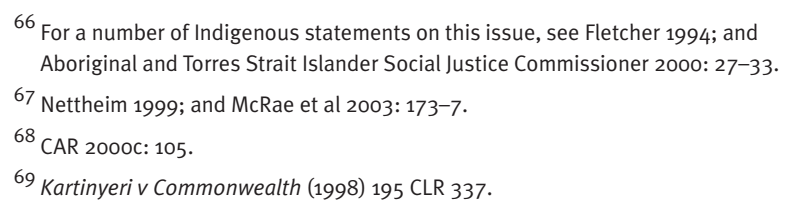




\section{Treaties and agreements}

Recommendation 5 in the Council's Final Report ${ }^{70}$ proposed negotiation of a process to achieve 'agreements or treaties' to protect 'the political, legal, cultural and economic position of Aboriginal and Torres Strait Islander peoples'.

It is important to distinguish such a proposal from most of the other items on the list of 'unfinished business', which deal with particular issues that are said to require resolution. The proposal for a treaty of agreement is simply one possible means for expressing resolution of such issues. However this general proposition should be qualified in relation to the fundamental question of entry by Indigenous Australians into the Australian polity. A treaty (again, under that or some other name) seems to be the appropriate instrument to formalise such a high level 'reconciliation'.

The Commonwealth Government indicated in 2002 that is not interested in pursuing this proposal, or in proceeding with the draft legislation which the Council referred to in Recommendation 6, and attached to its Final Report. ${ }^{71}$

\section{Ongoing processes}

The Council's Recommendation 6 contemplated a process for negotiating how unresolved issues might be identified and resolved. The Commonwealth Government has supported the ongoing process of reconciliation in a less specific sense by committing some funds to the new foundation, Reconciliation Australia. And there is a general commitment to 'practical Reconciliation', which seems to refer to the Citizenship Rights aspects of the Indigenous agenda, ie, overcoming disadvantage. Otherwise, the list of 'unfinished business' remains to be addressed.

And some of the matters have been referred to monitoring committees under the several human rights treaties to which Australia is a party. During 2000, for example, matters concerning Indigenous Australians were considered, in the context of consideration of Australia's periodic reports, by the expert committees under ICCPR, ICESCR, ICERD and the Convention against Torture and Other Cruel, Inhuman or Degrading Treatment or Punishment. ${ }^{72}$

\section{Conclusion}

There was no treaty basis for the establishment of the several British colonies in Australia, nor was there Indigenous consent to subsequent constitutional developments in Australia. A negotiated settlement of this fundamental issue would seem to deserve incorporation in a 'treaty', whether under that or some other name.

A number of other items of 'unfinished business' have also been nominated for settlement by negotiation between Indigenous peoples and Australia. The outcomes of such negotiations could also be incorporated in a treaty or treaties. But some may be adequately incorporated in constitutional amendments, or in legislation, or in other measures. Indeed it would be unfortunate for negotiated settlements on some issues to need to wait for settlement of all issues.

\footnotetext{
${ }^{70}$ CAR 2000c: 106. $\quad{ }^{71}$ Commonwealth of Australia 2002: 646-50; $\quad 7^{72}$ UN 1984, [1989] ATS 21. McRae et al 2003: 646-50.
} 
In summary, my general proposition is that there are strong bases in International Law generally, and International Human Rights Law in particular, to support the case for a 'treaty' between Indigenous peoples and Australia. There are also clear bases in International Human Rights Law to support Indigenous peoples in their search for resolution of the outstanding issues, the 'unfinished business', that they have identified.

\section{Acknowledgments}

Some of the argument of this paper was later presented in McCrae et al, 2003.

\section{References}

\section{Books, articles and reports}

Anaya, JS 1996, Indigenous Peoples in International Law, Oxford University Press, New York.

Aboriginal and Torres Strait Islander Commission (ATSIC) 1995, Recognition, Rights and Reform, AGPS, Canberra.

Aboriginal and Torres Strait Islander Social Justice Commissioner 1995, Indigenous Social Justice: Strategies and Recommendations, HREOC, Sydney.

— 2000, Social Justice Report 2000, HREOC, Sydney.

- 2001, Native Title Report 2000, HREOC, Sydney.

ATSIC Treaty Project, available at www.treatynow.org

ATSIC and AIATSIS 2003, Treaty - Let's Get It Right!, Aboriginal Studies Press, Canberra.

Australian Law Reform Commission 1986, The Recognition of Aboriginal Customary Laws, Report No. 31, AGPS, Canberra.

Bennett, JM and AC Castles 1979, A Source Book of Australian Legal History, Law Book Co, Sydney.

Brennan, F 1999, 'The Prospects for National Reconciliation following the post-Wik Standoff of Government and Indigenous leaders', UNSWLJ 22: 618-24.

Brennan, F and J Crawford, 1990, 'Aboriginality, Recognition, and Australian Law: Where to from Here', 1(1), Public Law Review 1(1): 53-79.

Brennan, S, L Behrendt, L Strelein and G Williams 2005, Treaty, The Federation Press, Sydney.

Collings, N and R Jacobsen 1999, 'Reconciliation with Australia's Young Indigenous people', UNSWLJ 22: 647-54.
Commonwealth of Australia 2002, Commonwealth Government response to the Council for Aboriginal Reconciliation final report-Reconciliation: Australia's challenge, AGPS, Canberra.

Council for Aboriginal Reconciliation (CAR) 1995, Going forward: social justice for the First Australians, CAR, Canberra.

- 2000a, Australian declaration towards reconciliation, AGPS, Canberra, reproduced in Appendix 1, CAR 2000c.

— 200ob, Roadmap for reconciliation, CAR, Canberra.

- 2000c, RECONCILIATION. Australia's challenge, CAR, Canberra.

— 2000d, National strategy for overcoming disadvantage, CAR, Canberra.

Dodson M and Sarah Pritchard 1998, 'Recent Developments in Indigenous Policy: The Abandonment of Self-Determination', Indigenous Law Bulletin 4(15): 4-8.

Dodson, P 1999, 'Lingiari - Until The Chains Are Broken', 4th Vincent Lingiari Memorial Lecture,1999, reproduced in M Grattan (ed) 2000, Reconciliation: Essays on Australian Reconciliation, Bookman Press, Melbourne: 264-74.

Eggleston, E 1976, Fear, Favour or Affection, ANU Press, Canberra.

Evatt, E 1996, Review of the Aboriginal and Torres Strait Islander Heritage Protection Act 1984, AGPS, Canberra.

- 1998, 'Overview of State and Territory heritage legislation', Indigenous Law Bulletin 4(16): 4-8.

Fletcher, C (ed) 1994, Aboriginal self-determination in Australia, Aboriginal Studies Press, AIATSIS, Canberra. 
Human Rights and Equal Opportunity Commission 1997, Bringing them home, HREOC, Sydney.

Janke, T 1998, Our culture: our future. Report on Australian Indigenous cultural and intellectual property right, Michael Frankel \& Co, Sydney.

— 1999, 'Respecting Indigenous cultural and intellectual property rights', UNSWLJ 22: 631-9.

Jull, P 1996, 'An Aboriginal policy for the Millennium: the three social justice reports', Australian Indigenous Law Reporter 1(1): 1-13.

LIAC (Legal Information Access Centre) 2001, Hot topics: reconciliation, State Library of NSW, Sydney.

Martinez, M Alfonso 1999, The Treaty Study (Final report, 1999): E/CN.4/Sub.2/1999/20.

Martinez Cobo, J 1986, Study of the problem of discrimination against Indigenous populations, Volume 4: conclusions, proposals and recommendations, UN Doc. E/CN.4/Sub.2/1986/ Add.4.

McRae, H, G Nettheim and L Beacroft 1997, Indigenous legal issues: commentary and materials, 2nd edn, Law Book Co, Sydney.

McRae, H, G Nettheim, L Beacroft and L McNamara, 2003, Indigenous legal issues: commentary and materials, 3rd edn, Law Book Co, Sydney.

Nettheim, G 1993, “"The Consent of the natives": Mabo and Indigenous political rights', The Sydney Law Review 15: 223, reprinted in Essays on the Mabo decision, Law Book Co, Sydney.

- 1999a, 'Indigenous Australians and the Constitution', in Reform - A Journal of National and International Law Reform 74, Australian Law Reform Commission.

- 1999b, 'Reconciliation and the Constitution', UNSWLJ 22: 625-30.

— 2001a, 'Making a difference: reconciling our differences', Newc LR 5(1): 3-37.

- 2001b, 'Reconciliation: challenges for Australian law', Australian Journal of Human Rights 7(1): 47.

Nettheim, G, GD Meyers and D Craig 2002, Indigenous peoples and governance structures, Aboriginal Studies Press, AIATSIS, Canberra.

Pritchard, S 1998, 'The Right of Indigenous Peoples to Self-Determination', in The Laws of Australia, Title 1, Aborigines and Torres Strait Islanders, 1.7
International Law, chapter 6, part B, para [66].

— 1999, 'Forging new relationships: some observations on the processes of reaching agreement on a document/documents of reconciliation', 22 UNSWLJ 22: 609-17.

Pritchard S and C Heindow-Dolman, 1998, 'Indigenous peoples and international law: a critical overview,' Australian Indigenous Law Reporter 3: 473-509.

Race Discrimination Commissioner 1995, Racial Discrimination Act 1975: a review, AGPS, Canberra.

Reynolds, H 1987, The Law of the Land, Penguin, Ringwood.

Royal Commission into Aboriginal Deaths in Custody 1991, National Report, AGPS, Canberra.

Senate Standing Committee on Constitutional and Legal Affairs 1983, 'Two Hundred Years Later - A Report on the Feasibility of a Compact or 'Makaratta' between the Commonwealth and Aboriginal People', AGPS, Canberra.

— 1988, Final Report, AGPS, Canberra.

Steering Committee for the Review of Government Service Provision 2005, Overcoming Indigenous disadvantage: key indicators 2005, Productivity Commission, Melbourne.

Steiner, HJ and P Alston 2000, International human rights in context: law, politics, morals, 2nd edn, Oxford University Press, New York.

The American Society of International Law 1984, 'Are Indigenous Populations Entitled to International Juridical Personality?' in Proceedings, SeventyNinth Annual Meeting: 189-208.

The Laws of Australia 1998, Law Book Co, Sydney.

The Macquarie Dictionary, 3rd edn, 1997, The Macquarie Library Pty Ltd, Macquarie University, NSW.

The Oxford English Dictionary 1970, vol XI, Clarendon Press, Oxford.

Tingle, Laura 1996, 'Behind the Lines: The Speech that Split a Nation', Age, 15 November, reproduced in H McRae, G Nettheim and L Beacroft 1997, Indigenous legal issues: commentary and materials, 2nd edn, Law Book Co, Sydney; 20-3.

Webber, J 1999, 'Native Title as self-government', UNSWLI 22: 600-3.

Wilkinson, C 1987, American Indians, time and the law, Yale University Press, New Haven. 


\section{International Covenants and Conventions}

Charter of the United Nations 1945, UN, San Francisco.

Convention on the Rights of the Child UN 1989, New York, [1991] ATS 428 ILM 1448.

Convention against Torture and Other Cruel, Inhuman or Degrading Treatment or Punishment UN 1984, [1989] ATS 21.

Declaration on Principles of International Law Concerning Friendly Relations and Co-operation among States in Accordance with the Charter of the United Nations 1970, G.A. Res. 2625, Oct 24 1970, UNGAOR, 25th Session, Supp 28, at 121, UN Doc. A/8028 (1971).

Draft Declaration on the Rights of Indigenous Peoples 1993, UN, Geneva, UN Doc E/CN.4/ Sub.2/1993/26.

ILO Convention Concerning Indigenous and Tribal Peoples in Independent Countries (No. 169) 1989, 328 UNTS 247.

International Convention on the Elimination of All Forms of Racial Discrimination (ICERD) 1966, 660 UNTS 195.

International Covenant on Civil and Political Rights (ICCPR) 1966, New York, 999 UNTS 171.

International Covenant on Economic, Social and Cultural Rights (ICESCR) 1966, New York, 993 UNTS 3.

Montevideo Convention on the Rights and Duties of States, December 1933, 49 Stat.3097, 3100, 165 LNTS 19, 25, League of Nations, Geneva.

UN Committee on the Elimination of Racial Discrimination general recommendation XXIII(51) (18 August 1997), as set out in [1998] Australian Indigenous Law Reporter 142.

Vienna Convention on the Law of Treaties 1969, 23 May 1969, 1155 UNTS 331.

\section{Legislation}

Aboriginal and Torres Strait Islander Heritage Protection Act 1954 (Cth).

Indian Appropriations Act of 1871 (USA) 16 Stat. 544, 566 (1871).

Hindmarsh Island Bridge Act 1997 (Cth).

Native Title Act 1993 (Cth).

Racial Discrimination Act 1975 (Cth).

Restatement of the Law (Third). The Foreign Relations Law of the United States 1988, American Law Institute, St Paul.

\section{Case law}

Kartinyeri v Commonwealth (1998) 195 CLR 337.

Mabo v Queensland (Mabo (No. 1) (1988) 166 CLR 186. Mabo v Queensland (Mabo (No. 2) (1992) 175 CLR 1. 